\title{
The impact of pulmonary valve-sparing techniques on postoperative early and midterm results in tetralogy of Fallot repair
}

\author{
Pulmoner kapak koruma yöntemlerinin Fallot tetralojisi tamirinde \\ erken ve orta dönem sonuçlara etkisi
}

\author{
Selim Aydın $\mathbb{1}^{1}$, Dilek Suzan $\mathbb{D}^{1}$, Bahar Temur $\mathbb{1}^{1}$, Barış Kırat $\mathbb{D}^{2}$, Müzeyyen İyigün $\mathbb{(}^{2}$, \\ İbrahim Halil Demir $\mathbb{B}^{3}$, Ender Ödemiş $\mathbb{B}^{3}$, Ersin Erek ${ }^{1}$
}

\begin{abstract}
'Department of Cardiovascular Surgery, Medicine Faculty of Acıbadem Mehmet Ali Aydınlar University, Atakent Hospital, ìstanbul, Turkey ${ }^{2}$ Department of Anesthesiology and Reanimation, Medicine Faculty of Acıbadem Mehmet Ali Aydınlar University, Atakent Hospital, istanbul, Turkey ${ }^{3}$ Department of Pediatric Cardiology, Medicine Faculty of Acıbadem Mehmet Ali Aydınlar University, Atakent Hospital, istanbul, Turkey
\end{abstract}

\section{ABSTRACT}

Background: In this study, we analyzed the impact of pulmonary valve-sparing techniques on early and midterm postoperative results of tetralogy of Fallot repair.

Methods: A total of 64 patients diagnosed with tetralogy of Fallot, who underwent total correction operation by the same surgeon between November 2010 and September 2015 were included in this retrospective study. Mean age of the patients was $20.0 \pm 14.2$ months (5.5-96 months). Forty patients $(62.5 \%)$ were male. Thirty two of the patients $(50 \%)$ were under one year of age. Pulmonary valve-sparing techniques were performed in 29 patients (Group 2), while transannular patch was applied in the remaining 35 patients (Group 1). Pericardial monocusp valve was constructed in 15 patients in Group 1. In Group 2, pulmonary valve-sparing techniques were transatrial repair in nine patients; transatrial-transpulmonary in eight, infundibular patch in eight, and infundibular-pulmonary patch in four patients.

Results: There was no early postoperative mortality in Group 2. Five patients $(14.2 \%)$ in Group 1 died in the early postoperative period $(\mathrm{p}=0.058)$. Pulmonary monocusp insertion was performed in $2(13.3 \%)$ of these patients $(p=1)$. The causes of mortality were sudden cardiac arrest $(n=2)$, multiorgan failure $(n=1)$, low cardiac output $(n=1)$, and neurological complications $(n=1)$. Five patients in Group 1 required extracorporeal membrane oxygenation support (ECMO). Three of them were separated from ECMO and two of the patients that were separated were discharged uneventfully. Total postoperative morbidity rate was significantly higher in Group $1(51.4 \%$ vs. $6.8 \%)(\mathrm{p}=0.0001)$. Morbidity rate was significantly lower in patients with pulmonary monocusp insertion than patients in the same group without a monocusp $(\mathrm{p}=0.0176)$. Forty nine $(83 \%)$ of the patients were followed up for a median of 6.5 (1-24) months. While free pulmonary regurgitation was detected in all non-monocusp patients in Group 1, pulmonary regurgitation was absent or mild in Group 2. Twelve $(80 \%)$ of the patients in Group 1 who had monocusp insertion were followed up. Only two of these patients had free pulmonary regurgitation $(16.6 \%)$. The rest of them had mild $(n=6)$ or mildmoderate pulmonary regurgitation $(n=4)$.

Conclusion: Mortality and morbidity rates are lower when pulmonary valvesparing techniques are used in repair of tetralogy of Fallot. Monocusp pulmonary valve insertion may improve results in patients who require transannular patch repair. It is suggested that every effort should be made to achieve a competently working pulmonary valve during repair.

Keywords: Monocusp; pulmonary valve-sparing; tetralogy of Fallot; transannular patch.
$\ddot{O} Z$

Amaç: Bu çalışmada pulmoner kapă̆ı korunarak ameliyat edilen hastalar, transanüler yama tekniği uygulanan hastalarla erken ve orta dönem sonuçları açısından incelendi.

Çalışma planı: Fallot tetralojisi tanısı ile Kasım 2010 - Eylül 2015 tarihleri arasında aynı cerrah tarafından tam düzeltme uygulanan toplam 64 hasta bu çalışmaya dahil edildi. Hastaların ortalama yaşı $20.0 \pm 14.2$ ay (5.5-96 ay) idi. Kırk hasta (\%62.5) erkek idi. Otuz iki hasta (\%50) bir yaşın altındaydı. Otuz beş hastaya transanüler yama tekniği ile (Grup 1), 29 hastaya pulmoner kapak koruma tekniği ile (Grup 2) cerrahi uygulandı. Grup 1'deki hastaların 15 'ine otojen perikard ile pulmoner monokusp oluşturuldu. Grup 2'deki hastaların dokuzuna transatriyal, sekizine transatriyal-transpulmoner, sekizine infundibüler yama, dördüne kombine infundibüler ve pulmoner yama ile tam düzeltme uyguland.

Bulgular: Grup 2'de erken mortalite görülmedi. Grup 1'de beş hasta (\%14.2) erken dönemde kaybedildi ( $\mathrm{p}=0.058)$. Bu hastaların ikisine monokusp replasmanı (\%13.3) uygulanmıştı $(\mathrm{p}=1)$. Mortalite nedenleri ani kardiyak arrest $(n=2)$, multiorgan yetmezliği $(n=1)$, düşük kardiyak debi $(n=1)$, nörolojik komplikasyon $(n=1)$ idi. Grup 1'de beş hasta ekstrakorporeal membran oksijenasyon (ECMO) desteğine alındı. Üç hasta ECMO'dan ayrıldı. ECMO'dan ayrılan iki hasta sorunsuz taburcu edildi. Total ameliyat sonras1 morbidite oranı Grup 1'de anlamlı olarak yüksekti (\%51.4'e karşın \%6.8) $(\mathrm{p}=0.0001)$. Grup 1'de pulmoner monokusp uygulanan hastalarda morbidite oranı aynı gruptaki diğer hastalara göre anlamlı olarak düşüktü $(\mathrm{p}=0.0176)$. Hastalardan 49'u (\%83), median 6.5 ay (1-24 ay) takip edildi. Grup 1'de monokusp uygulanmayan tüm hastalarda serbest pulmoner kapak yetmezliği saptanırken, grup 2'deki hastalarda pulmoner kapak yetmezliği yoktu veya hafif derecede idi. Grup 1 içerisindeki monokusp uygulanan hastaların 12'si (\%80) takip edildi. Bu hastaların sadece ikisinde serbest pulmoner kapak yetmezliği (\%16.6) tespit edildi. Geri kalanlarda hafif $(n=6)$ veya hafif-orta pulmoner kapak yetmezliği $(\mathrm{n}=4)$ vardi.

Sonuç: Fallot tetralojisi tamiri sırasında, pulmoner kapağı korunan hastalarda mortalite ve morbidite daha düşüktür. Transanüler yama gereken hastalarda monokusp pulmoner kapak uygulaması sonuçları iyileştirebilir. Tamir sırasında kompetan bir pulmoner kapak elde etmek için çaba gösterilmesi önerilebilir.

Anahtar sözcükler: Monokusp; pulmoner kapak koruma; Fallot tetralojisi; transanüler yama.

Received: November 03, 2017 Accepted: March 15, 2018

Correspondence: Selim Aydın, MD. Acıbadem Mehmet Ali Aydınlar Üniversitesi Tıp Fakültesi, Atakent Hastanesi, Kalp ve Damar Cerrahisi Kliniği, 34303 Halkalı, İstanbul, Turkey. Tel: +90412 - 2580060 e-mail: draydinselim@yahoo.com 
Tetralogy of Fallot (TOF) is one of the most common cyanotic congenital heart defects. The most common surgical repair method in most cases is to close the ventricular septal defect (VSD) via right ventriculotomy and expand the right ventricular outflow tract (RVOT) with a transannular patch (TAP) ${ }^{[1]}$ However, in patients undergoing TAP, right ventricular dysfunction may develop in the early and late period as a result of acute and chronic volume overload due to pulmonary valve insufficiency and re-intervention may be necessary for pulmonary valve replacement. ${ }^{[2]}$ Therefore, methods such as transatrial VSD closure and transatrial RVOT resection $^{[3]}$ or patch plasty together with transatrialtransplumonary repair ${ }^{[4]}$ have been developed.

Pulmonary valve-sparing techniques may be performed in patients with adequate pulmonary annulus diameter according to body mass index. However, in patients with narrow pulmonary annulus, expanding of RVOT with TAP may be inevitable. Studies also show that pulmonary monocusp replacement is useful in reducing right ventricular volume overload and pulmonary valve insufficiency in patients undergoing TAP. $^{[5]}$

This study compares patients who underwent surgery with valve-sparing techniques to those who underwent surgery with the transannular patch technique, in terms of early and midterm results.

\section{PATIENTS AND METHODS}

Our retrospective study received ATADEK-2016/16 numbered 2016-16/14 Ethics Committee approval on 10/13/2016. A total of 64 patients diagnosed with tetralogy of Fallot who had undergone total correction operation by the same surgeon between November 2010 and September 2015 were included in the study. Mean age of the patients was $20.0 \pm 14.2$ months (5.5-96 months). Forty patients $(62.5 \%)$ were male. Thirty-two patients $(50 \%)$ were under one year of age.
The demographic and preoperative characteristics of the patients are shown in Table 1 . Transannular patch technique was performed in 35 patients (Group 1), while 29 patients were repaired with pulmonary valvesparing techniques (Group 2). Pulmonary monocusp was constructed with autogenous pericardium in 15 patients in Group 1. ${ }^{[5]}$ In Group 2, pulmonary valve-sparing techniques were transatrial repair in nine patients; transatrial-transpulmonary in eight, infundibular patch in eight, and infundibular-pulmonary patch in four patients. Patients in Group 1 were significantly younger than the patients in Group $2(p=0.035)$. There was no statistical significance in terms of weight of the patients in both groups $(\mathrm{p}=0.129)$ (Table 1$)$.

All patients were preoperatively evaluated with transthoracic echocardiography and diagnostic angiography. Annulus diameter and pulmonary artery anatomy of the patients were evaluated with angiography and pressures were measured. Total correction operation was performed on patients with a McGoon ratio over 1.6.

Cardiopulmonary bypass (CPB) with aorto-bicaval cannulation, moderate hypothermia $\left(30-32^{\circ} \mathrm{C}\right)$ and intermittent antegrade isothermic blood cardioplegia was performed on all patients. The shunts of previously shunted patients were closed. RVOT was approached with slight retraction of the tricuspid valve after right atriotomy. Patients requiring transatrial repair underwent resection of the parietal and septal bands of the RVOT, and the RVOT and pulmonary valve were checked with Hegar dilators. In cases of inadequate clearance, longitudinal pulmonary arteriotomy was performed to resect the remaining muscle bands in the RVOT, and pulmonary valve tethering was corrected with commissural takedown, and adherent commissures were expanded with valvotomy. In patients with stenosis of the branches of the pulmonary artery, the incision was extended

Table 1. Demographic and preoperative characteristics of the patients

\begin{tabular}{|c|c|c|c|c|c|c|c|c|c|}
\hline \multirow[t]{2}{*}{ Characteristics } & \multicolumn{4}{|c|}{ Group $1(n=35)$} & \multicolumn{4}{|c|}{ Group $2(n=29)$} & \multirow[b]{2}{*}{$p$} \\
\hline & $\mathrm{n}$ & $\%$ & Mean \pm SD & Min-Max & $\mathrm{n}$ & $\%$ & Mean \pm SD & Min-Max & \\
\hline Age (months) & & & $17.5 \pm 11.0$ & $5.5-48$ & & & $22.8 \pm 16.9$ & $8-96$ & 0.035 \\
\hline Weight (kg) & & & $9.4 \pm 2.2$ & $5-14.9$ & & & $10.7 \pm 3.47$ & $6.7-24.6$ & 0.129 \\
\hline Gender (male) & 22 & 63 & & & 18 & 62 & & & 1 \\
\hline Previous shunt & 2 & 5.7 & & & 5 & 17.2 & & & 0.22 \\
\hline Coronary artery anomaly & 0 & 0 & & & 2 & 6.9 & & & 0.2 \\
\hline Preoperative hypoxic spell & 4 & 11.4 & & & 1 & 3.4 & & & 0.36 \\
\hline
\end{tabular}

SD: Standard deviation. 
to include the areas with stenosis, and reconstruction was performed.

In the patients who had long tunnel type stenosis in the infundibulum, an incision of approximately $2-3 \mathrm{~cm}$ was made in the right ventricular infundibulum, the residual bands were excised, and the stenosis was widened with an additional infundibular patch.

In patients with insufficient valve clearance despite pulmonary valvotomy, the arteriotomy was transannularly extended towards the RVOT and TAP was performed. Pulmonary monocusp was constructed with autogenous pericardium in 15 of the patients who underwent transannular repair.

Transannular, infundibular and pulmonary artery incisions were closed with an autogenous or, when inadequate, bovine pericardial patch. All patients' VSDs were closed transatrially with interrupted teflonsupported sutures using polyethylene terephthalate fiber (Dacron) patch.

After CPB, all patients underwent intraoperative transesophageal echocardiography to evaluate VSD patch and presence of residual obstruction. Right ventricle $(\mathrm{RV}) /$ left ventricle (LV) ratio was calculated by measuring RV and aorta (Ao) pressures. Ratio above 0.8 was accepted as criteria for repeat reconstruction of RVOT.

\section{Statistical analysis}

Statistical analysis was performed using SPSS program version 11.5 (SPSS Inc., Chicago, IL, USA) designed for Windows software. All data was given as mean \pm standard deviation. The Mann-Whitney $\mathrm{U}$ test was used to compare the mean values between the groups, and the Chi-square and Fisher's exact test were used to compare the ratios between the groups. $\mathrm{P}$ value of $<0.05$ was considered statistically significant.

\section{RESULTS}

There were no early mortalities in Group 2. Five patients (14.2\%) in Group 1 died within the early postoperative period ( $\mathrm{p}=0.058$ ). Monocusp replacement had been performed in two (13.3\%) of these patients $(p=1)$. Mortality causes were sudden cardiac arrest in one patient, sepsis and multiple organ failure in two patients, multiple organ failure due to low cardiac output in one patient, and neurological complication in one patient. Five patients in Group 1 received veno-arterial extracorporeal membrane oxygenation (ECMO) support with central cannulation. Indications for ECMO were extracorporeal cardiopulmonary resuscitation (ECPR) in two patients, low cardiac output in one patient, respiratory arrest in one patient, and respiratory arrest secondary to seizure in one patient. Three patients were removed from ECMO and two of these patients were discharged uneventfully.

One patient in Group 1 was reoperated due to residual VSD within the early postoperative period. Permanent pacemaker implantation was performed in two patients in Group 2 due to complete heart block. In Group 1, low cardiac output developed in four patients $(\mathrm{p}=0.12)$. Six patients in Group 1 and one patient in Group 2 required prolonged mechanical ventilation $(p=0.12)$. Four patients in Group 1 and one patient in Group 2 underwent peritoneal dialysis $(p=0.36)$. In Group 1, pleural effusion developed in four patients $(p=0.12)$. While there was no statistical significance when morbidities were evaluated separately, the total postoperative morbidity rate was significantly higher in Group 1 (Table 2). In Group 1, the morbidity rate of patients who underwent pulmonary monocusp insertion was significantly lower than the other patients of the same group $(\mathrm{p}=0.0176)$ (Table 3$)$.

Forty nine $(83 \%)$ of the patients were followed up for a median of 6.5 months (1-24 months). While free

Table 2. Postoperative early mortality and morbidity

\begin{tabular}{|c|c|c|c|c|c|}
\hline & \multicolumn{2}{|c|}{ Group $1(n=35)$} & \multicolumn{2}{|c|}{ Group $2(n=29)$} & \multirow[b]{2}{*}{$p$} \\
\hline & $\mathrm{n}$ & $\%$ & $\mathrm{n}$ & $\%$ & \\
\hline Low cardiac output & 4 & 11.4 & 0 & 0 & 0.12 \\
\hline Prolonged mechanical ventilation & 6 & 17.1 & 1 & 3.4 & 0.12 \\
\hline Peritoneal dialysis & 4 & 11.4 & 1 & 3.4 & 0.36 \\
\hline Pleural effusion & 4 & 11.4 & 0 & 0 & 0.12 \\
\hline Total morbidity & 18 & 51.4 & 2 & 6.8 & 0.0001 \\
\hline Mortality & 5 & 14.2 & 0 & 0 & 0.058 \\
\hline
\end{tabular}


Table 3. Early mortality and morbidity of patients with and without monocusp in Group 1

\begin{tabular}{lccccccc}
\hline & \multicolumn{2}{l}{ Monocusp $(-)(\mathrm{n}=20)$} & & \multicolumn{2}{l}{ Monocusp $(+)(\mathrm{n}=15)$} & \\
\cline { 2 - 3 } & $\mathrm{n}$ & $\%$ & & $\mathrm{n}$ & $\%$ & $p$ \\
\hline Low cardiac output & 3 & 15 & & 1 & 6.6 & 0.62 \\
Prolonged mechanical ventilation & 4 & 20 & & 2 & 13.3 & 0.68 \\
Peritoneal dialysis & 3 & 15 & & 1 & 6.6 & 0.62 \\
Pleural effusion & 4 & 20 & & 0 & 0 & 0.12 \\
Total morbidity & 14 & 70 & & 4 & 26.7 & $\mathbf{0 . 0 1 7 6}$ \\
Mortality & 3 & 15 & & 2 & 13.3 & 1 \\
\hline
\end{tabular}

pulmonary regurgitation $(\mathrm{PR})$ was detected in all patients in Group 1 that underwent TAP without monocusp insertion, PR was absent or mild in Group 2. Twelve $(80 \%)$ of the patients in Group 1 that underwent TAP with monocusp insertion were followed up. Free PR was detected in only two $(16.6 \%)$ of these patients. The rest had mild PR $(n=6)$ or mild-moderate PR $(n=4)$.

\section{DISCUSSION}

While early term results have improved after the introduction of total correction operation of TOF, studies on mid and long-term results have shown that pulmonary insufficiency, progressive RV dysfunction, reduced functional capacity, arrhythmia, and sudden mortality due to these complications may occur in patients who have undergone surgery with the TAP technique. ${ }^{[6-8]}$

Today, total correction operation is performed with less than 5\% risk in many centers around the world. In our study, the total mortality rate was $7.8 \%$. Two of the exitus patients had the lowest weight of the study group $(5.5$ and $6 \mathrm{~kg}$ ). One of the patients suffered a hypoxic spell before surgery and underwent an emergent operation. Another one of the exitus patients underwent a hypoxic spell during preoperative angiography. All of the exitus patients were from the TAP group. While there was no significant difference in terms of mortality in the patients with monocusp insertion, there was a significant decrease in morbidity. In a study by Saygi et al. ${ }^{[9]}$ of 122 patients who had undergone total correction operation, it was reported that nine patients $(7.3 \%)$ were lost and perioperative early term mortality determinants were poor preoperative oxygenation, presence of coronary anomaly, development of block in the early postoperative period, high right ventricular pressure, and need for postoperative ECMO support.
Right ventricle/left ventricle peak systolic pressure rate was an important criteria in the postoperative evaluation of presence of RVOT stenosis. Katz et al. ${ }^{[10]}$ reported that $\mathrm{RV} / \mathrm{LV}$ pressure ratio above 0.85 caused 2.5 times increased mortality risk and 7.3 times increased risk of reoperation. Hirsch et al. ${ }^{[1]}$ conducted a study on 61 newborn patients diagnosed with TOF that underwent total correction operation, and found that $\mathrm{RV} / \mathrm{LV}$ pressure ratio over 0.7 was a risk factor for reoperation. Again, Stewart et al. ${ }^{[8]}$ reported a reoperation incidence of $33 \%$ for patients with RV/LV pressure ratio above 0.7 in a study of 102 patients. We also considered the maximum acceptable $\mathrm{RV} / \mathrm{LV}$ pressure ratio to be 0.8 , and that RVOT should be reviewed when RVOT is over 0.8 .

The monocusp may be constructed with various materials such as autogenous or bovine pericardium, polytetrafluoroethylene (PTFE) membrane, and extracellular matrix. ${ }^{[12,13]}$ In standard practice, the monocusp is prepared by cutting it as a semicircle to fit the length of the RVOT incision from the apex to the pulmonary annulus and the width of the diameter of the pulmonary annulus. The monocusp is attached by leaving $1 \mathrm{~mm}$ excess on both sides and suturing it to the pulmonary valve commissures and the apex of the RVOT incision at three different points. The suture used to close the transannular incision is continued on both ends and stitched to the ventriculotomy. ${ }^{[12,13]}$ Likewise, we applied monocusp with autogenous pericardium with the standard technique in all of our patients. While the literature describes various new techniques on pulmonary valve reconstruction, the superiority of these techniques to the standard monocusp application in terms of durability and degeneration is under debate. ${ }^{[14,15]}$

There are conflicting results in the literature on the impact of pulmonary valve-sparing methods on early outcomes. Enc et al. ${ }^{[16]}$ conducted a study on 
71 patients who underwent total correction operation with valve-sparing techniques, and reported early mortality in four patients (5.6\%), and early morbidity in eight patients (11.3\%) (revision for bleeding in 2 patients, supraventricular arrhythmia in 6 patients). Postoperative echocardiography revealed mild PR in 51 patients $(76.1 \%)$ and moderate PR in $13(19.4 \%)$ in their study. Retrospective evaluation of 724 patients by Park et al. ${ }^{[17]}$ did not reveal any significant difference in terms of length of extubation, intensive care, and hospitalization in patients who underwent valvesparing methods compared to other patients. In a study of 163 patients, Sasson et al. ${ }^{[12]}$ reported that there was less pleural drainage and shorter ventilation and length of intensive care in patients with pulmonary monocusp than those who underwent TAP alone. They found similar results in patients who underwent monocusp insertion in terms of early PR development leading to necessary early intervention ( $91 \%$ mild PR, $6 \%$ moderate PR, 3\% free PR at discharge). However, Sasikumar et al. ${ }^{[13]}$ reported that a significant majority of the patients who had undergone monocusp insertion showed monocusp calcification and loss of mobility along with associated pulmonary valve insufficiency and/or pulmonary stenosis within the postoperative first year follow-up. In general, it has been reported that the monocusp technique, which has controversial mid and late-term results and seems to have limited durability, has at least adequate function at an early stage and the potential to reduce postoperative mortality and morbidity. ${ }^{[5,12,13]}$

In conclusion, we believe that, considering the early and late benefits, when pulmonary annulus diameter is adequate, every effort should be made to protect the pulmonary valve in patients undergoing total repair for tetralogy of Fallot. In patients with narrow pulmonary annulus undergoing transannular patch, monocusp insertion is a technique that could potentially reduce postoperative morbidity and mortality by conserving function of the pulmonary valve and right ventricle in the early stage.

\section{Declaration of conflicting interests}

The authors declared no conflicts of interest with respect to the authorship and/or publication of this article.

\section{Funding}

The authors received no financial support for the research and/or authorship of this article.

\section{REFERENCES}

1. Gott VL. C. Walton Lillehei and total correction of tetralogy of Fallot. Ann Thorac Surg 1990;49:328-32.
2. Chaturvedi RR, Redington AN. Pulmonary regurgitation in congenital heart disease. Heart 2007;93:880-9.

3. Edmunds LH Jr, Saxena NC, Friedman S, Rashkind WJ, Dodd PF. Transatrial repair of tetralogy of Fallot. Surgery 1976;80:681-8.

4. Pacifico AD, Sand ME, Bargeron LM Jr, Colvin EC. Transatrial-transpulmonary repair of tetralogy of Fallot. J Thorac Cardiovasc Surg 1987;93:919-24.

5. Brown JW, Ruzmetov M, Vijay P, Rodefeld MD, Turrentine MW. Right ventricular outflow tract reconstruction with a polytetrafluoroethylene monocusp valve: a twelve-year experience. J Thorac Cardiovasc Surg 2007;133:1336-43.

6. Bacha EA, Scheule AM, Zurakowski D, Erickson LC, Hung J, Lang P, et al. Long-term results after early primary repair of tetralogy of Fallot. J Thorac Cardiovasc Surg 2001;122:154-61.

7. Horneffer PJ, Zahka KG, Rowe SA, Manolio TA, Gott VL, Reitz BA, et al. Long-term results of total repair of tetralogy of Fallot in childhood. Ann Thorac Surg 1990;50:179-83.

8. Stewart RD, Backer CL, Young L, Mavroudis C. Tetralogy of Fallot: results of a pulmonary valve-sparing strategy. Ann Thorac Surg 2005;80:1431-8.

9. Saygi M, Ergul Y, Tola HT, Ozyilmaz I, Ozturk E, Onan IS, et al. Factors affecting perioperative mortality in tetralogy of Fallot. Pediatr Int 2015;57:832-9.

10. Katz NM, Blackstone EH, Kirklin JW, Pacifico AD, Bargeron LM Jr. Late survival and symptoms after repair of tetralogy of Fallot. Circulation 1982;65:403-10.

11. Hirsch JC, Mosca RS, Bove EL. Complete repair of tetralogy of Fallot in the neonate: results in the modern era. Ann Surg 2000;232:508-14.

12. Sasson L, Houri S, Raucher Sternfeld A, Cohen I, Lenczner O, Bove EL, et al. Right ventricular outflow tract strategies for repair of tetralogy of Fallot: effect of monocusp valve reconstruction. Eur J Cardiothorac Surg 2013;43:743-51.

13. Sasikumar D, Sasidharan B, Tharakan JA, Dharan BS, Mathew T, Karunakaran J. Early and 1-year outcome and predictors of adverse outcome following monocusp pulmonary valve reconstruction for patients with tetralogy of Fallot: A prospective observational study. Ann Pediatr Cardiol 2014;7:5-12.

14. Quintessenza JA, Jacobs JP, Morell VO, Giroud JM, Boucek RJ. Initial experience with a bicuspid polytetrafluoroethylene pulmonary valve in 41 children and adults: a new option for right ventricular outflow tract reconstruction. Ann Thorac Surg 2005;79:924-31.

15. Gil-Jaurena JM, Ferreiros M, Castillo R, Conejo L, Cuenca $\mathrm{V}$, Zabala JI. se of a pulmonary neovalve with a transannular patch for repair of tetralogy of fallot. Rev Esp Cardiol 2010;63:1438-43.

16. Enç Y, Aydemir NA, Yalçın Y, Özsoy D, Erdem A, Özay B, et al. Fallot tetralojisi: Transatriyal/transpulmoner yaklaşımın erken dönem sonuçları. Turk Gogus Kalp Dama 2007;14:157-9.

17. Park CS, Lee JR, Lim HG, Kim WH, Kim YJ. The longterm result of total repair for tetralogy of Fallot. Eur J Cardiothorac Surg 2010;38:311-7. 